\title{
Al-Nb-V (Aluminum-Niobium-Vanadium)
}

\section{Raghavan}

In a previous study, an isothermal section at $1000{ }^{\circ} \mathrm{C}$ was determined for this system by [1966Ram], which depicts one ternary compound. Recently, [2005Jia] reported partial isothermal sections at 1500,1300 , and $1100{ }^{\circ} \mathrm{C}$, showing the tie-lines between the $A 15$ compound $\mathrm{Nb}_{3} \mathrm{Al}$ and the bcc solid solution $(\mathrm{Nb}, \mathrm{V})$.

\section{Binary Systems}

The Al-Nb phase diagram [Massalski2] depicts three intermediate phases: $\mathrm{Nb}_{3} \mathrm{Al}\left(A 15, \mathrm{Cr}_{3}\right.$ Si-type cubic), $\mathrm{Nb}_{2} \mathrm{Al}$ $\left(D 8_{b}, \sigma C r F e-t y p e\right.$ tetragonal), and $\mathrm{NbAl}_{3}\left(D 0_{22}, \mathrm{TiAl}_{3}-\right.$ type tetragonal). The Al-V phase diagram [2004Gon, Massalski2] depicts five intermetallic compounds: $\mathrm{V}_{5} \mathrm{Al}_{8}$ (D8 ${ }_{2}, \mathrm{Cu}_{5} \mathrm{Zn}_{8}$-type cubic), $\mathrm{VAl}_{3}\left(\mathrm{DO}_{22}, \mathrm{TiAl}_{3}\right.$-type tetragonal), $\mathrm{V}_{4} \mathrm{Al}_{23}$ (hexagonal), $\mathrm{V}_{7} \mathrm{Al}_{45}$ (monoclinic), and $\mathrm{V}_{2} \mathrm{Al}_{21}$ (cubic). $\mathrm{Nb}$ and $\mathrm{V}$ form a continuous bcc solid solution at all temperatures below the melting range.

\section{Ternary Isothermal Sections}

[2005Jia] prepared seven Nb-rich ternary alloys in a transferred-arc plasma melter under Ar atm. The alloys were given a final anneal at 1500,1300 , and $1100{ }^{\circ} \mathrm{C}$ for $200 \mathrm{~h}$ and quenched in water. The phase equilibria were studied with scanning and transmission electron microscopy and energy dispersive $\mathrm{x}$-ray spectroscopy. The partial isothermal sections constructed by [2005Jia] at 1500, 1300, and $1100{ }^{\circ} \mathrm{C}$ are shown in Fig. 1. The tie-lines between co-existing compositions of $A 15$ and bcc phases are shown [2005Jia]. $\mathrm{Nb}_{3} \mathrm{Al}(A 15)$ dissolves at least 25 at.\% $\mathrm{V}$ at these temperatures.

The morphology of the precipitate $\left(\mathrm{Nb}_{3} \mathrm{Al}\right)$ and its orientation relationship with the bcc matrix are among the other features studied by [2005Jia].

\section{References}

1966Ram: A. Raman, X-ray Investigation of Some T-T ${ }^{5}-\mathrm{Al}$ Systems, Z. Metallkd., 1966, 57(7), p 535-540, in German

2004Gon: W. Gong, Y. Du, B. Huang, R. Schmid-Fetzer, C. Zhang, and $\mathrm{H}$. Xu, Thermodynamic Reassessment of the Al-V System, Z. Metallkd., 2004, 95(11), p 978-986

2005Jia: H. Jiao, F. Barradas, T. Rong, I.P. Jones, and M. Aindow, The Microstructural Evolution of NbAlV Alloys, Intermetallics, 2005, 13, p 1157-1165

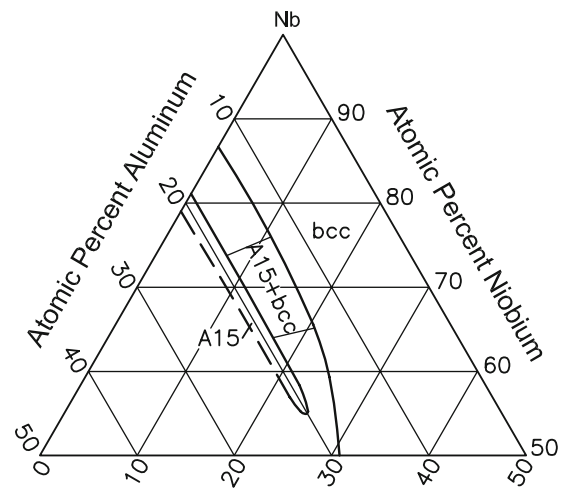

Atomic Percent Vanadium

(a)

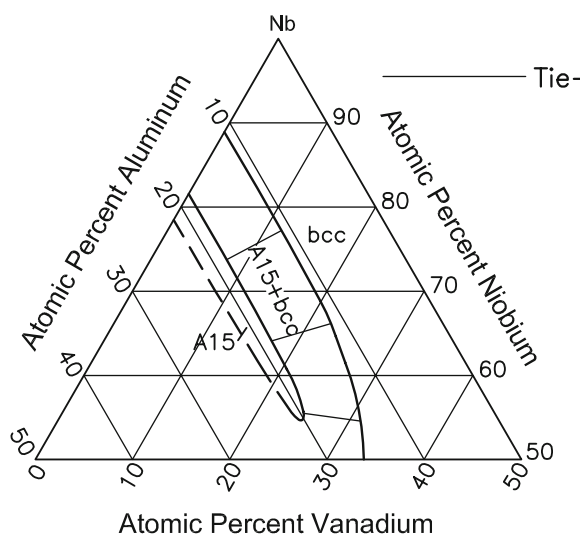

(b)

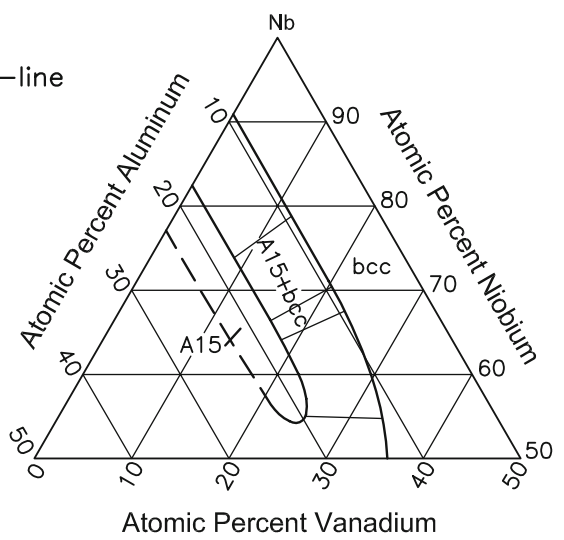

(c)

Fig. 1 Al-Nb-V partial isothermal sections at (a) 1500, (b) 1300 , and (c) $1100{ }^{\circ} \mathrm{C}$ [2005Jia] 